\title{
Protective Effect of Boiled and Freeze-dried Mature Silkworm Larval Powder Against Diethylnitrosamine-induced Hepatotoxicity in Mice
}

\author{
Jae-Min Cho ${ }^{1}$, Kee-Young Kim², Sang-Deok Ji ${ }^{2}$, Eun-Hee Kim ${ }^{1}$ \\ ${ }^{1}$ College of Pharmacy and Institute of Pharmaceutical Sciences, CHA Bio Complex, CHA University, Seongnam, ${ }^{2}$ Department of Agricultural Biology, \\ National Academy of Agricultural Science, Rural Development Administration, Jeonju, Korea
}

\begin{abstract}
Background: Hepatocellular carcinoma (HCC) is a representative inflammation-associated cancer and known to be the most frequent tumors. HCC may also induce important pro- and anti-tumor immune reactions. However, the underlying mechanisms are unsatisfactorily identified. We investigated the protective effect of boiled and freeze-dried mature silkworm larval powder (BMSP) on diethylnitrosamine (DEN)-induced hepatotoxicity in mice.

Methods: Mice were fed with diet containing $\operatorname{BMSP}(0.1,1$, and $10 \mathrm{~g} / \mathrm{kg})$ for two weeks and DEN (100 mg/kg, intraperitoneally) was injected 18 hours before the end of this experiment. Liver toxicity was determined in serum and histopathological examination was assessed in the liver tissues. Infiltration of immune cells and expressions of inflammatory cytokines and chemokines were also examined. Results: Pretreatment with BMSP reduced necrotic and histopathological changes induced by DEN in the liver. Measurement of serum biochemical indicators, the levels of alkaline phosphatase, alanine aminotransferase, and aspartate aminotransferase, showed that pretreatment with BMSP also decreased DEN-induced hepatotoxicity. In addition, BMSP inhibited the macrophage and CD31 infiltration in a dose-dependent manner. The expressions of interleukin-1 $\beta$, IFN- $\gamma$ and chemokines for $T$ cell activation were decreased in BMSP pretreatment groups.
\end{abstract}

Conclusions: BMSP may have a protective effect against acute liver injury by inhibiting necrosis and inflammatory response in DEN-treated mice.

(J Cancer Prev 2016;21:173-181)

Key Words: Diethylnitrosamine, Bombyx mori powder, Hepatocellular carcinoma, IFN-gamma

\section{INTRODUCTION}

Hepatocellular carcinoma (HCC) is known to be occurred by chronic hepatitis. Chronic inflammation affects continuous cell division and causes random genetic injury, leading to hepatocarcinogenesis. ${ }^{1,2}$ Diethylnitrosamine (DEN) is a representative hepatocarcinogen found in various foods, alcohol, and tobacco smoke. The main source of N-nitrosamines is protein, which is produced from nitrate precursor. The gastric acid can activate the amines to N-nitrosamines. ${ }^{3.4}$ Various hepatocarcinogen such as DEN cause liver damage and promote hepatocellular carcinogenesis in animal models. DEN can increase cell proliferation or hepatocellular necrosis in the liver, thereby inducing the initiation of carcinogenesis. ${ }^{5.7}$ The treatment with DEN also leads to genetic changes in hepatocytes during initiation. ${ }^{8}$ DEN has to be metabolized by cytochrome P450 enzymes, such as CYP2E1, in the liver, which causing DNA-adducts via an alkylation mechanism. ${ }^{9.10}$ This activation procedure has been regarded as an important step for the initiation of HCC. ${ }^{10}$ In addition, DEN has been reported that induce the production of reactive oxygen species causing cellular damage and oxidative stress. ${ }^{3,11,12}$

Recent evidences report that some immune factors play a key role in the prognosis of tumor. ${ }^{13,14}$ The immune system in the host might recognize tumor antigens and turn on the specific

Received September 1, 2016, Revised September 6, 2016, Accepted September 7, 2016

Correspondence to: Eun-Hee Kim

College of Pharmacy and Institute of Pharmaceutical Sciences, CHA Bio Complex, CHA University, 335 Pangyo-ro, Bundang-gu, Seongnam 13488, Korea Tel: +82-31-881-7179, Fax: +82-31-850-9315, E-mail: ehkim@cha.ac.kr, ORCID: Eun-Hee Kim, http://orcid.org/0000-0002-8523-0440

Copyright (C) 2016 Korean Society of Cancer Prevention

(c) This is an Open Access article distributed under the terms of the Creative Commons Attribution Non-Commercial License (http://creativecommons.org/icenses/by-nc/4.0) which permits unrestricted non-commercial use, distribution, and reproduction in any medium, provided the original work is properly cited. 
innate and/or adaptive immune reaction to inhibit carcinogenesis. ${ }^{15}$ On the contrary, cancers may activate several mechanisms to avoid host immune system. ${ }^{13}$ Several cytokines also have been reported to have influence on the progression of hepatocarcinogenesis. ${ }^{16}$

Bombyx mori, a major species for sericulture, has been cultivated for a long time. Silkworms have been used to produce important agricultural by-products for more than 5,000 years since the first record found in China that was dated back to 2,700 $\mathrm{BC} .{ }^{17}$ Recently, the applications for silkworm byproducts have not been limited to making fabrics using silk from cocoons. In addition to eating silkworm pupae, several important functional materials have been discovered in silkworm byproducts. Control of blood glucose concentrations has been shown to be induced by silk protein hydrolysate, ${ }^{18-20}$ improvements in male sexual function have been shown to be induced by male silkworm pupal extracts, ${ }^{21}$ enhancements in cognitive function have been shown to be induced by degraded silk fibroin proteins ${ }^{22,23}$ and protection against alcoholic hepatotoxicity has been reported by silkworm excrement powder. ${ }^{24}$ Recently, we have developed a technique for processing mature silkworm larvae that were formerly inedible because of the hardness of their silk glands. ${ }^{25}$ Mature silkworm larvae have an enlarged silk gland and other organelles that are enriched with the previously identified functional materials mentioned above. ${ }^{18-24}$ In this study, we investigated the protective effects of boiled and freeze-dried mature silkworm larval powder (BMSP) pretreatment against acute liver damage induced by DEN treatment. Pretreatment with BMSP significantly abrogated the up-regulated serum biochemical markers of hepatotoxicity, histopathological change, and recruitment of immune cells via inhibition of pro-inflammatory chemokines and cytokines.

\section{MATERIALS AND METHODS}

\section{Boiled mature silk worm larval powder production}

BMSP was made as previously described. ${ }^{25}$ Briefly, live mature larvae of the B. moriwhite-jade cocoon strain (also known as Baek $\mathrm{Ok} \mathrm{Jam})^{26}$ that were reared by mulberry leaves were immediately smothered for 130 minutes at $100^{\circ} \mathrm{C}$ with steam using an electric pressure-free cooking machine (KumSeong Ltd., Bucheon, Korea), followed by freeze-drying with a freeze-drier (FDT-8612; Operon Ltd., Gimpo, Korea) for 24 hours. Larvae were then grinded using a hammer mill (HM001; Korean Pulverizing Machinery Co. Ltd., Incheon, Korea) and a disk mill (Disk Mill01; Korean Pulverizing Machinery Co. Ltd.). The lengths of particles of BMSP were shorter than $0.1 \mathrm{~mm}$. The BMSP was stored at $-50^{\circ} \mathrm{C}$ and then used for formulating diet for mouse.

\section{The preparation of diets containing boiled and freeze-dried mature silkworm larval powder}

AIN-76A and BMSP-containing AIN-76A (BMSP-AIN-76A) diets were purchased from DBL (Umsung, Korea). Briefly, BMSP were mixed with powdered AIN-76A, then this mixture were dried and prepared as a pellet chow by DBL. Three different amounts of BMSP were added to AIN-76A; low dose ( $1 \mathrm{~g} / \mathrm{kg}$ of AIN-76A for the treatment with $0.1 \mathrm{~g} / \mathrm{kg}$ of mouse body weight), middle dose (10 $\mathrm{g} / \mathrm{kg}$ of AIN-76A for the treatment with $1 \mathrm{~g} / \mathrm{kg}$ of mouse body weight) and high dose (100 g/kg of AIN-76A for the treatment with $10 \mathrm{~g} / \mathrm{kg}$ of mouse body weight). Three different concentrations of mouse diet were similarly formulated.

\section{Animal and experimental design}

The C57BL/6 mice were purchased from Orient Bio (Seoul, Korea). Mice were fed with sterilized AIN-76A or BMSP-AIN-76A and sterile water ad libitum, and housed in an air-conditioned room on a 12-hour light/dark cycle at a temperature of $24^{\circ} \mathrm{C}$. Animals were handled in an accredited animal facility in accordance with international policies of animal center of the CHA University. Mice randomly divided into five groups as follows; (a) control group ( $\mathrm{n}=6$ ) with commercial diet, AIN-76A, (b) DEN group $(\mathrm{n}=10)$ with AIN-76A, (c) DEN +0.1 group $(\mathrm{n}=$ 8) with $0.1 \mathrm{~g} / \mathrm{kg}$ BMSP, (d) DEN +1 group $(\mathrm{n}=8)$ with $1 \mathrm{~g} / \mathrm{kg}$ BMSP, (e) DEN + 10 group $(\mathrm{n}=8)$ with $10 \mathrm{~g} / \mathrm{kg}$ BMSP. Mice were fed with AIN-76A or BMSP-AIN-76A diet for two weeks and then treated with DEN (100 mg/kg, intraperitoneally) for 18 hours. Control group received vehicle instead of DEN. DEN and other chemicals were supplied from Sigma-Aldrich (St. Louis, MO, USA).

\section{Blood and tissue samples}

All mice were sacrificed by taking blood via cardiac puncture under carbon monoxide anesthesia after treatment with DEN for 18 hours. The livers were rapidly removed, rinsed with PBS, and kept in ice. The materials were stored at $-80^{\circ} \mathrm{C}$ until they were analyzed.

\section{Hepatic histopathological and immunohistoche- mical assessments}

For histopathological assessment, fixed liver portions were embedded in paraffin blocks, followed by cutting $4 \mu \mathrm{m}$ sections and mounting them on glass slides for hematoxylin-eosin (H\&E) 
staining. Hepatocyte ballooning is a form of liver cell injury recognized as a swollen hepatocyte with a rarefied cytoplasm. For immunohistochemical assessment, $4 \mu \mathrm{m}$ paraffin-embedded liver sections were mounted on coated glass slides for detection of proteins under investigation. After antigen retrieval and blocking endogenous peroxidases and nonspecific protein binding, slide sections were incubated first with primary antibodies, followed by horseradish peroxidase-conjugated secondary antibodies. Then, the chromogen was added for color development. The primary antibodies for F4/80 and CD31 (diluted 1:100) were purchased from Santa Cruz Biotechnology (Santa Cruz, CA, USA). All slides were developed with 3,3' diaminobenzidine followed by hematoxylin counterstaining. Scoring was done by the corresponding author, who was blinded as to the primary antibodies and the treatment groups. For F4/80 and CD31, the percentage of positively stained cells was estimated: 1 for $5 \%$ or fewer, 2 for $5 \%$ to $20 \%, 3$ for $20 \%$ to $50 \%, 4$ for $50 \%$ to $80 \%$, and 5 for $80 \%$ or more.

\section{Serum biochemical parameters of hepatic injury}

Hepatic injury was evaluated biochemically by measuring the activities of alkaline phosphatase (ALP), alanine aminotransferase (ALT), and aspartate aminotransferase (AST) in serum using Hitachi automatic analyzer 7600-210 (Hitachi High-Technologies Corporation, Tokyo, Japan).

\section{Reverse transcription-PCR}

The hepatic messenger RNA (mRNA) was isolated with RiboEX (GeneAll, Seoul, Korea). The liver tissues in RiboEX were incubated for 10 minutes at $4^{\circ} \mathrm{C}$. Furthermore, $100 \mu \mathrm{L}$ of chloroform was added and gently mixed. After incubation for 10 minutes on ice, samples were centrifuged at 12,000 rpm for 15 minutes. Supernatants were mixed with $500 \mu \mathrm{L}$ of isopropanol and incubated at $4^{\circ} \mathrm{C}$ for 15 minutes. After centrifuging at 12,000 rpm for 10 minutes, pellets were washed with $70 \%(\mathrm{v} / \mathrm{v})$ ethanol. After allowing the ethanol to completely evaporate, pellets were dissolved in $100 \mu \mathrm{L}$ of diethylenepyrocarbonate-treated water (Invitrogen Life Technologies, Carlsbad, CA, USA). Complementary DNA was prepared using reverse transcriptase originating from Murine Moloney leukemia virus (Promega, Madison, WI, USA), according to the manufacturer's instructions. PCR was performed for 30 cycles at $94^{\circ} \mathrm{C}$ for 20 seconds, $58^{\circ} \mathrm{C}$ for 30 seconds, and $72^{\circ} \mathrm{C}$ for 45 seconds. Oligonucleotide primers were as follows: interleukin (IL)-1 $\beta$ : sense 5'-CAG GCT CCG AGA TGA ACA ACA AAA-3', antisense 5'-TGG GGA ACT CTG CAG ACT CAA ACT-3'; IFN- $\gamma$ : sense 5'-ACA ATG AAC GCT ACA CAC TG-3', antisense 5'-TCA AAC TTG GCA ATA CTC AT-3'; CXCL11: sense 5'-CTG CTC AAG GCT TCC TTA TGT T-3', antisense 5'-CCT TTG TCG TTT ATG AGC CTT C-3': CCL17: sense 5'-CAG GAA GTT GGT GAG CTG GTA TA-3', antisense 5'-TTG TGT TCG CCT GTA GTG CAT A-3': CCR2: sense 5'-AGA GGT CTC GGT TGG GTT GT -3', antisense 5'-ATT ATA ACG TTC TGG GCA CC-3': and glyceraldehyde 3-phosphate dehydrogenase, sense 5'-GGT GCT GAG TAT GTC GTG GA-3', antisense 5'-TTC AGC TCT GGG ATG ACC TT-3'.

\section{Statistical analysis}

Results are expressed as the mean $\pm \mathrm{SD}$. The data were analyzed by one-way analysis of variance, and the statistical significance between groups was determined by Duncan's multiple range test. Statistical significance was accepted at $P<$ 0.05 .

\section{RESULTS}

\section{Boiled and freeze-dried mature silkworm larval powder decreased diethylnitrosamine-induced acute liver injury}

To examine the chemopreventive role of BMSP in hepatocarcinogenesis, we used a commonly used DEN-induced acute liver injury model. Single dose of $100 \mathrm{mg} / \mathrm{kg}$ DEN was intraperitoneally injected into 8-week old C57BL/6 mice after pretreatment with diet containing BMSP for two weeks. After 18 hours, mice were sacrificed and liver damage was assessed (Fig. 1A). Indeed, the percentage of liver weight versus body weight in DEN-treated mice was significantly decreased but significantly recovered by pretreatment with high dose of BMSP (Fig. 1B), suggesting that pretreatment with $10 \mathrm{~g} / \mathrm{kg}$ of BMSP could protect the liver injury induced by DEN. Normal liver structure was shown in no treatment groups histopathologically (Fig. 1C). H\&E stained liver sections demonstrated that DEN exposure for 18 hours provoked necrosis in the central and portal areas, infiltration of neutrophils and lymphocytes, and distinct edema around the central vein, and portal areas in DEN group (Fig. 1C). Considerable swelling cytoplasm and vacuolar degeneration in parenchymal cells were also observed. However, pretreatment with diet containing BMSP inhibited the hepatocyte damage induced by DEN in a dose-dependent manner. BMSP-fed group exhibited almost intact portal areas and decreased parenchymal necrosis. To examine the protective effects of BMSP against DEN-induced hepatotoxicity, the levels of three indicators in the serum, ALP, ALT, and AST, were measured. The activities of ALP, ALT, and AST were significantly increased in DEN-treated mice but decreased in 
A

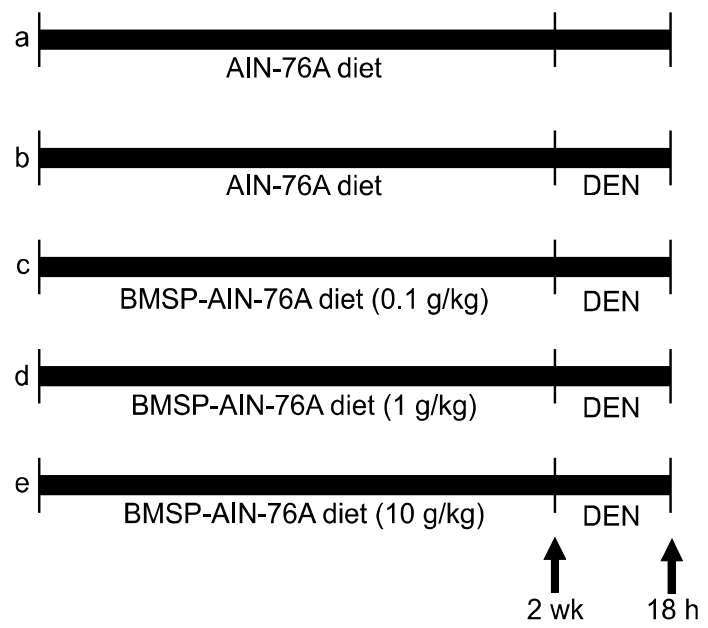

B

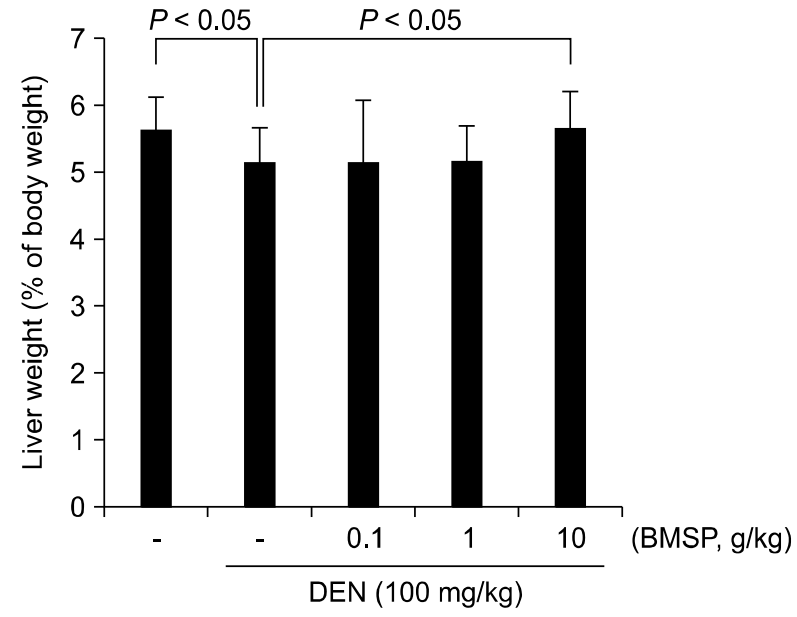

C

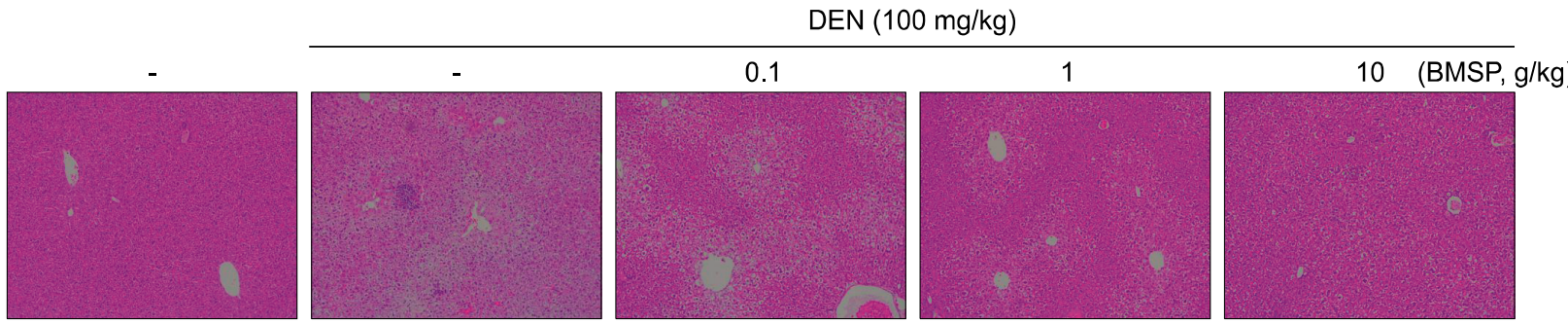

Figure 1. The effect of boiled and freeze-dried mature silkworm larval powder on diethylnitrosamine-induced acute liver injury. (A) Animal experimental design. Mice were fed with AIN-76A or diet containing BMSP $(0.1,1$, and $10 \mathrm{mg} / \mathrm{kg}$ ) for two weeks and then with DEN (100 $\mathrm{mg} / \mathrm{kg}$, intraperitoneally) for 18 hours. (B) Liver weight as percentage of body weight. The results represent means \pm SD of 6 to 10 mice per group. $P$-values are obtained from Student's $t$-test. (C) Representative histological sections from the livers of DEN-treated mice with or without BMSP. Histopathological sections of the livers were stained with H\&E $(\times 100)$. BMSP, boiled and freeze-dried mature silkworm larval powder; DEN, diethylnitrosamine.
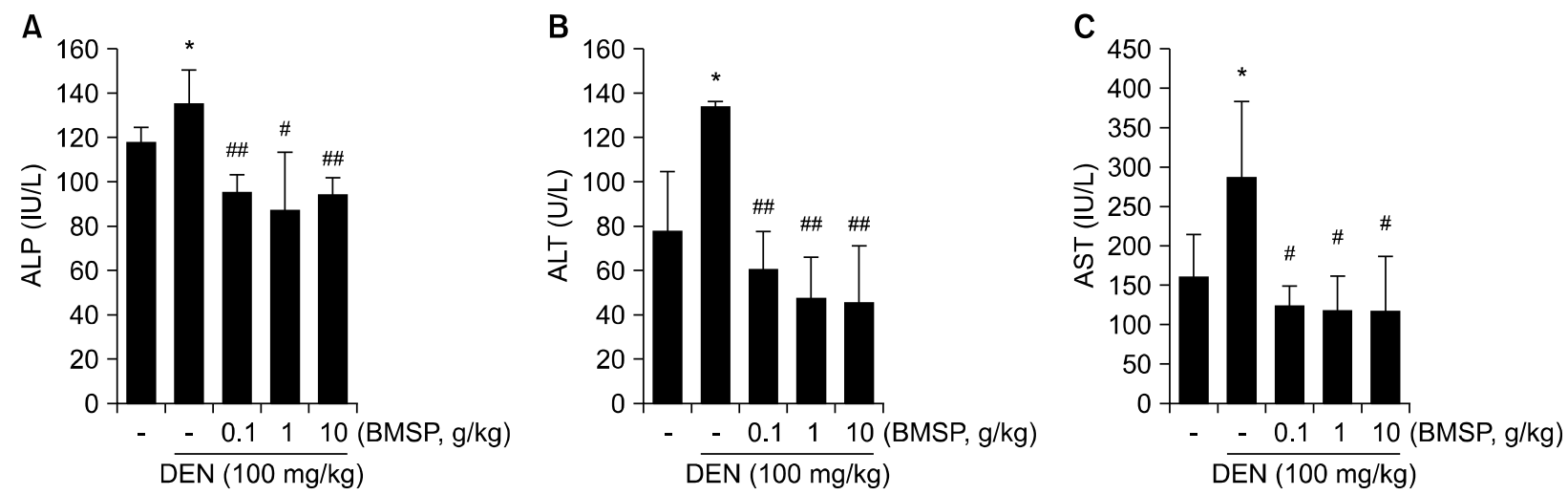

Figure 2. The effect of boiled and freeze-dried mature silkworm larval powder pretreatment on diethylnitrosamine-induced serum biochemical parameters. Serum (A) alkaline phosphatase (ALP), (B) alanine aminotransferase (ALT), and (C) aspartate aminotransferase (AST). The results are means $\pm \mathrm{SD}$ ( $\mathrm{n}=6-10$ per group). ${ }^{*} P<0.05$ vs. control group; ${ }^{\#} P<0.05,{ }^{\# \#} P<0.01$ vs. DEN group. BMSP, boiled and freeze-dried mature silkworm larval powder; DEN, diethylnitrosamine. 
BMSP-fed mice than DEN-treated mice (Fig. 2). These results demonstrate that BMSP pretreatment might have protective effects on DEN-induced hepatotoxicity.

2. Boiled and freeze-dried mature silkworm larval powder inhibits the recruitment of immune cells induced by diethylnitrosamine

Both pro- and anti-cancer immune reactions are found in HCC. ${ }^{27}$ Although DEN treatment does not induce carcinogenesis driven by chronic inflammation, the inflammatory reaction can regulate the initiation and progression of cancer. ${ }^{28}$ Therefore, we hypothesized that BMSP pretreatment may regulate immune system in this DEN-treated model. The infiltration of immune cells was compared in DEN group versus DEN + BMSP group. Immunohistochemical staining for F4/80 to localize macrophage and CD31 confirmed increased macrophage in DEN-treated group compared to untreated controls (Fig. 3A). However, pretreatment with BMSP inhibited the macrophage and CD31 infiltration in a dose-dependent manner (Fig. 3B). CD31 is a $130-\mathrm{kDa}$ transmembrane glycoprotein also known as platelet endothelial cell adhesion molecule- 1 and found in the surface of macrophages, platelets, neutrophils, and monocytes. CD31 performs a key role in the adhesion pathway between inflammatory cells and endothelial cells during inflammation. It promotes the migration of leucocyte to the endothelial cells during angiogenesis. ${ }^{29.30}$ CD31, one of the best factors for the detection of vascular cancer, stains monocytes and plasma cells. Collectively, these results demonstrated that pretreatment with BMSP may ameliorate DEN-induced recruitment of immune cells for the inflammatory reactions associated with hepatocellular carcinogenesis.

A
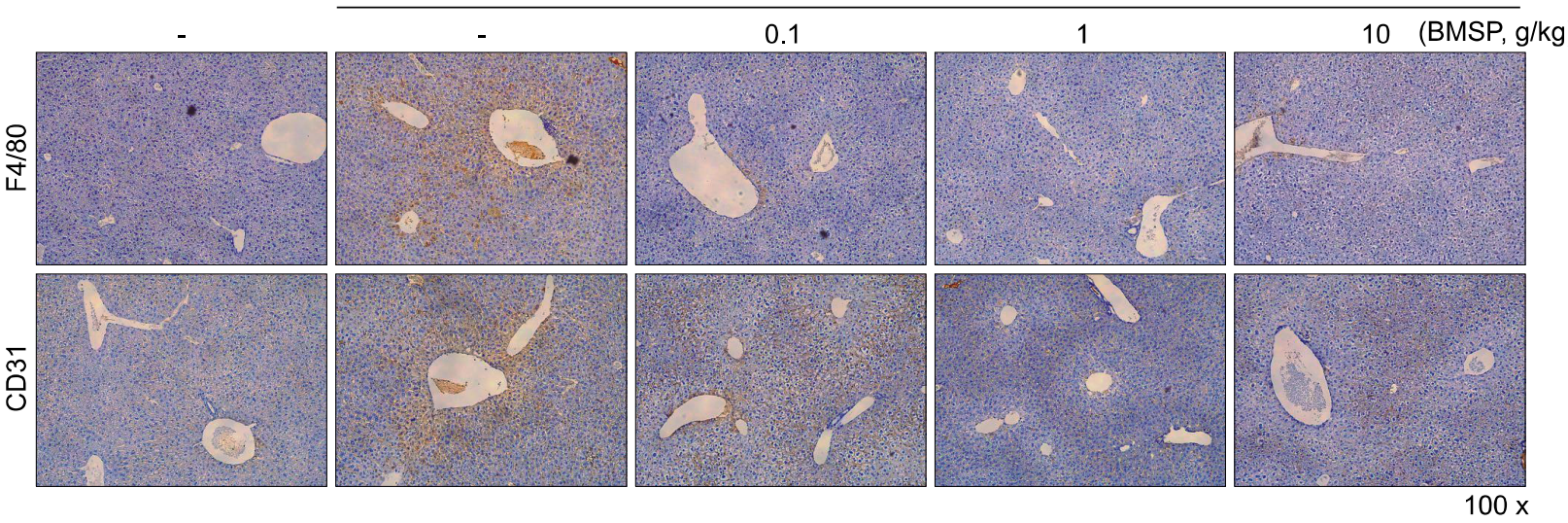

B
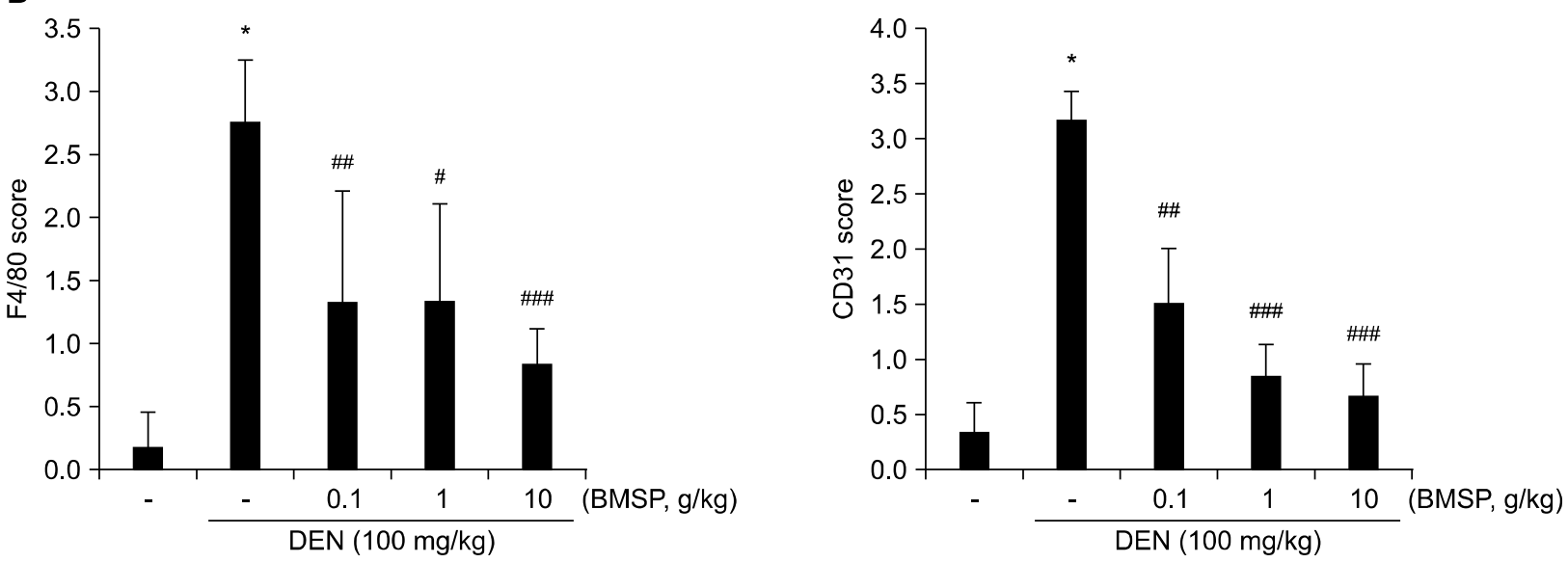

Figure 3. The effect of boiled and freeze-dried mature silkworm larval powder on immune cell recruitment in livers of diethylnitrosaminetreated mice. (A) Representative images of liver sections were stained by immunohistochemistry for F4/80 or CD31 ( $\times 100)$. Counterstaining was done with hematoxylin (blue staining). (B) Staining intensity were scored as 1 for $5 \%$ or fewer, 2 for $5 \%$ to $20 \%, 3$ for $20 \%$ to $50 \%$, 4 for $50 \%$ to $80 \%$, and 5 for $80 \%$ or more stained cells $* P<0.001$ vs. control group; ${ }^{\#} P<0.05$, ${ }^{\# \#} P<0.01$, and ${ }^{\# \# \# ~} P<0.001$ vs. DEN group. BMSP, boiled and freeze-dried mature silkworm larval powder; DEN, diethylnitrosamine. 


\section{Boiled and freeze- dried mature silkworm larval} powder inhibited diethylnitrosamine-induced inflammation

Following liver injury and the release of inflammatory mediators primarily from Kupffer cells, neutrophils and monocytes are recruited to the liver and subsequently amplify the inflammation response by secreting more inflammatory mediators. ${ }^{31}$ To study the effect of BMSP on inflammatory response in liver tissue, changes in the expression of pro-inflammatory chemokines and cytokines were determined by reverse transcription-PCR analysis. The expression of IL-1 $\beta$ mRNA was highly induced by DEN treatment. The expression of IL-1 $\beta$ mRNA, however, decreased in the diet containing BMSP-fed groups in a dose-dependent manner (Fig. 4A). The type II IFN response is orchestrated solely by IFN $-\gamma$ released from activated $\mathrm{T}$
A

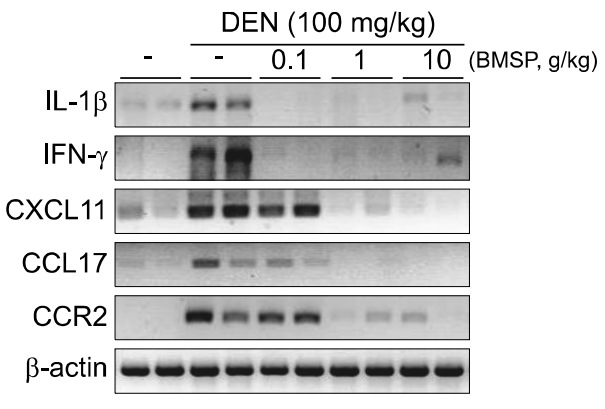

B
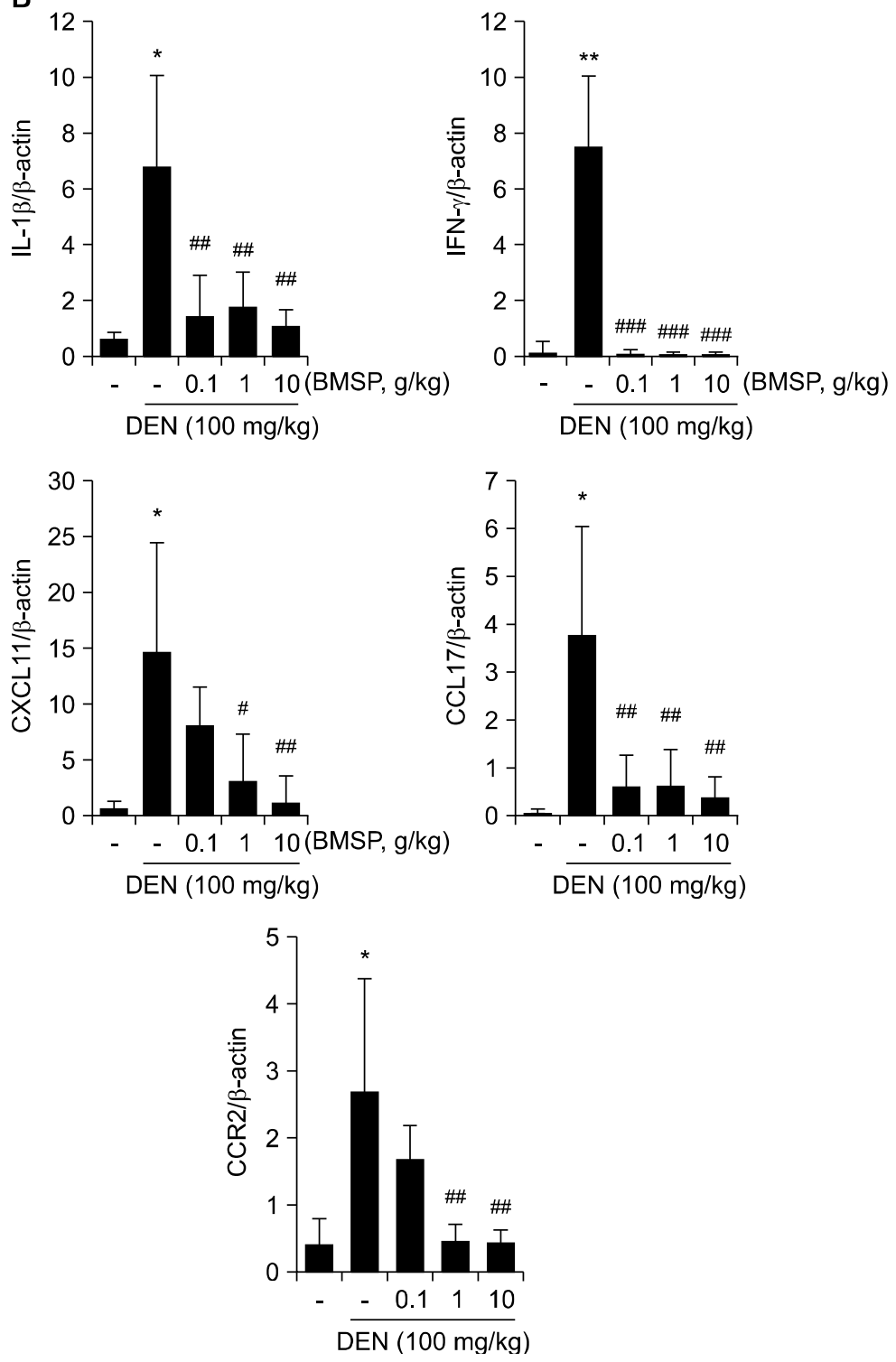

Figure 4. The effect of boiled and freeze-dried mature silkworm larval powder (BMSP) on diethylnitrosamine (DEN)-induced pro-inflammatory signaling. (A) Expressions of interleukin (IL)-1 $\beta$, IFN- $\gamma$, CXCL11, CCL17, and CCR2 mRNA were determined by reverse transcription-PCR. The expression level of $\beta$-actin was used to confirm the quality and quantity of total RNA from each sample. (B) Quantification of the each gene expression relative to vehicle control group. Data were obtained from all mice ( $\mathrm{n}=6-10$ per group) and are expressed as the means \pm SD. ${ }^{*} P<0.01$ and ${ }^{* *} P<0.001$ vs. control group; ${ }^{\#} P<0.05,{ }^{\# \#} P<0.01$, and ${ }^{\# \#} P<0.001$ vs. DEN group. BMSP, boiled and freeze-dried mature silkworm larval powder; DEN, diethylnitrosamine. 
cells and natural killer (NK) cells. IFN- $\gamma$ shows diverse roles in liver disorders, including pro-inflammatory, antiviral, and antitumor properties. ${ }^{32}$ Compared to the control mice, administration of DEN led to elevation of IFN- $\gamma$ levels; however, administration of BMSP, even at a dose of $0.1 \mathrm{~g} / \mathrm{kg}$, prior DEN resulted in attenuating this type II IFN response in mice (Fig. 4A). To confirm if down-regulation of the IFN- $\gamma$ mRNA affects the downstream signaling pathway, the expressions of chemokines for $\mathrm{T}$ cell activation, CXCL11 and CCL17, and a chemokine receptor CCR2 mRNA were measured in the liver. BMSP pretreatment significantly inhibited the expressions of CXCL11, CCL17, and CCR2 mRNA induced by DEN (Fig. 4B). These data indicate that pretreatment with BMSP can effectively protect the DEN-induced inflammation via inhibition of pro-inflammatory cytokines, especially IFN- $\gamma$.

\section{DISCUSSION}

DEN is usually employed to induce experimental HCC. The high dose of DEN, acting as an initiator in HCC, induces cell death and compensatory proliferation in the liver. ${ }^{5-7}$ DEN exposure can activate adjacent Kuppfer cells to induce compensatory proliferation, which is critical process in DEN-induced HCC. ${ }^{5-7}$ In this study, $100 \mathrm{mg} / \mathrm{kg}$ of DEN was injected and this dose was enough to induce cell death and initiate carcinogenesis in the liver. ${ }^{33}$ The major goal of this study was to identify the hepatoprotective effect of BMSP because several silkworm byproducts have been shown to give a wide range of health benefits, such as blood glucose control, ${ }^{18-20}$ improving male sexual function, ${ }^{21}$ enhancing cognitive function, 22,23 and protection against alcoholic hepatotoxicity. ${ }^{24}$ Because diet containing BMSP is enriched with diverse identified functional materials, such as silk fibroin proteins, flavonoids, polyphenols, vitamins, fatty acids, dietary fibers, and essential minerals, ${ }^{22}$ it may have unidentified health improvement effects. In this study, we examined the protective effects of BMSP against DEN-induced hepatotoxicity in C57BL/6 mice. Our results exhibit that BMSP pretreatment can prevent the hepatocyte necrosis, inflammatory response, and immune cell infiltration induced by DEN treatment.

Some animal studies have been reported to explain the link between inflammation and hepatocarcinogenesis. ${ }^{28,34,35}$ In these models, inhibitions of the immune response usually suppress liver cancer formation, ${ }^{35}$ which means that adaptive immune reactions are needed for the progression of tumor. To investigate the relationship between inflammation and the initiation of liver cancer, we utilized the mouse model treated with DEN. Although there is a report that DEN induces non-inflammatory liver cancer, ${ }^{36}$ DEN treatment generally induces HCC to be influenced by inflammation. DEN-induced HCC has been reported to cause a considerable leucocyte infiltration ${ }^{37}$ and increased numbers of hepatic macrophages and $\mathrm{T}$ cells. $^{28}$ Tumor-associated macrophages is known to connect with invasiveness of $\mathrm{HCC}{ }^{38}$ In this regard, the increase of $\mathrm{CD} 31$ and macrophages in the current DEN-induced liver injury model is in line with clinical results. Moreover, liver injury induced by DEN was accompanied with noticeable induction of pro-inflammatory chemokines and cytokines. Interestingly, we observed that IFN- $\gamma$ and $\mathrm{T}$ cellassociated chemokines/chemokine receptor (CCL17, CXCL11, and CCR2) were specifically induced in DEN-treated mouse livers. In the current study, the pretreatment with BMSP remarkably down-regulated the levels of inflammatory cytokines and $\mathrm{T}$ cell-associated chemokines induced by DEN. The type II IFN response is mediated by IFN- $\gamma$ produced predominantly by NK cells and $\mathrm{T}$ lymphocytes infiltrating the liver and implicated in the initiation step of DEN-induced hepatocarcinogenesis by increasing inflammatory signals, intrahepatic cytokine expression, and hepatocyte oxidative DNA damage. ${ }^{39,40}$ In the setting of initial liver injury, the hepatoprotective effect of BMSP against DEN treatment can be attributed to less production of IFN- $\gamma$ and IL-1 $\beta$. It is worthwhile mentioning, however, that decreased production of IFN- $\gamma$ by BMSP can be considered a double-edged sword, as it can decrease the initial liver injury.

Altogether, pretreatment with BMSP reduced necrotic and histopathological changes, as well as the activities of ALP, AST, and ALT induced by DEN in the liver. BMSP attenuated initial liver injury induced by DEN insult by suppressing the elevation of pro-inflammatory cytokines IL- $1 \beta$ and IFN- $\gamma$, which coincided with less inflammatory cell infiltration. Moreover, BMSP inhibited the expression of T cell-associated chemokines, CXCL11, and CCL17. Conclusively, BMSP may have a protective effect on acute liver damage by decreasing hepatotoxicity and inflammatory response in DEN-treated mice. Because HCC occurs in the tissues with inflammation and clearly provokes local hepatic and systemic inflammatory responses, intake of BMSP might be a useful strategy for the chemoprevention of HCC.

\section{ACKNOWLEDGMENTS}

This work was carried out with the support of the "Cooperative Research Program for Agriculture Science \& Technology Development (Project title: Elucidation the health improvement effects of boiled silk worm larvae, Project No: PJ010828012016) Rural 
Development Administration".

\section{CONFLICTS OF INTEREST}

No potential conflicts of interest were disclosed.

\section{REFERENCES}

1. Okuda K. Hepatocellular carcinoma: recent progress. Hepatology 1992;15:948-63.

2. Tsukuma H, Hiyama T, Tanaka S, Nakao M, Yabuuchi T, Kitamura $\mathrm{T}$, et al. Risk factors for hepatocellular carcinoma among patients with chronic liver disease. N Engl J Med 1993;328:1797-801.

3. Jayakumar S, Madankumar A, Asokkumar S, Raghunandhakumar S, Gokula dhas K, Kamaraj S, et al. Potential preventive effect of carvacrol against diethylnitrosamine-induced hepatocellular carcinoma in rats. Mol Cell Biochem 2012;360:51-60.

4. Janani P, Sivakumari K, Geetha A, Ravisankar B, Parthasarathy C. Chemopreventive effect of bacoside A on $\mathrm{N}$-nitrosodiethylamineinduced hepatocarcinogenesis in rats. J Cancer Res Clin Oncol 2010;136:759-70.

5. Maeda S, Kamata H, Luo JL, Leffert H, Karin M. IKKbeta couples hepatocyte death to cytokine-driven compensatory proliferation that promotes chemical hepatocarcinogenesis. Cell 2005;121: 977-90.

6. Glauert HP, Calfee-Mason K, Stemm DN, Tharappel JC, Spear BT. Dietary antioxidants in the prevention of hepatocarcinogenesis: a review. Mol Nutr Food Res 2010;54:875-96.

7. Qiu W, Wang X, Leibowitz B, Yang W, Zhang L, Yu J. PUMA-mediated apoptosis drives chemical hepatocarcinogenesis in mice. Hepatology 2011:54:1249-58.

8. Vásquez-Garzón VR, Rouimi P, Jouanin I, Waeg G, Zarkovic N, Villa-Treviño S, et al. Evaluation of three simple direct or indirect carbonyl detection methods for characterization of oxidative modifications of proteins. Toxicol Mech Methods 2012;22: 296-304.

9. Verna L, Whysner J, Williams GM. N-nitrosodiethylamine mechanistic data and risk assessment: bioactivation, DNA-adduct formation, mutagenicity, and tumor initiation. Pharmacol Ther 1996;71:57-81.

10. Kang JS, Wanibuchi H, Morimura K, Gonzalez FJ, Fukushima S. Role of CYP2E1 in diethylnitrosamine-induced hepatocarcinogenesis in vivo. Cancer Res 2007;67:11141-6.

11. Amin A, Hamza AA, Bajbouj K, Ashraf SS, Daoud S. Saffron: a potential candidate for a novel anticancer drug against hepatocellular carcinoma. Hepatology 2011;54:857-67.

12. Ghosh D, Choudhury ST, Ghosh S, Mandal AK, Sarkar S, Ghosh A, et al. Nanocapsulated curcumin: oral chemopreventive formulation against diethylnitrosamine induced hepatocellular carcinoma in rat. Chem Biol Interact 2012;195:206-14.

13. Finn OJ. Cancer immunology. N Engl J Med 2008;358:2704-15.

14. Schreiber RD, Old LJ, Smyth MJ. Cancer immunoediting: integrating immunity's roles in cancer suppression and promotion. Science 2011;331:1565-70.

15. Vesely MD, Kershaw MH, Schreiber RD, Smyth MJ. Natural innate and adaptive immunity to cancer. Annu Rev Immunol 2011;29:235-71.
16. Budhu A, Wang XW. The role of cytokines in hepatocellular carcinoma. J Leukoc Biol 2006;80:1197-213.

17. Cherry R. History of sericulture. Bull Entomol Soc Am 1987; 33:83-4.

18. Do SG, Park JH, Nam H, Kim JB, Lee JY, Oh YS, et al. Silk fibroin hydrolysate exerts an anti-diabetic effect by increasing pancreatic $\beta$ cell mass in C57BL/KsJ-db/db mice. J Vet Sci 2012;13:339-44.

19. Kim MJ, Hong SJ, Yang J, Kim HK. Silkworm (Bombyx mori L.) reduces vasopressin expression in the hypothalamus of streptozotocin-induced diabetic mice. Neurol Res 2007;29 Suppl 1:S72-7.

20. Jung EY, Lee HS, Lee HJ, Kim JM, Lee KW, Suh HJ. Feeding silk protein hydrolysates to $\mathrm{C} 57 \mathrm{BL} / \mathrm{Ks} J-\mathrm{db} / \mathrm{db}$ mice improves blood glucose and lipid profiles. Nutr Res 2010;30:783-90.

21. Oh HG, Lee HY, Kim JH, Kang YR, Moon DI, Seo MY, et al. Effects of male silkworm pupa powder on the erectile dysfunction by chronic ethanol consumption in rats. Lab Anim Res 2012;28: 83-90.

22. Kang YK, Lee W, Kang B, Kang H. Memory-enhancing effects of silk fibroin-derived peptides in scopolamine-treated mice. J Microbiol Biotechnol 2013;23:1779-84.

23. Kim DK, Kang YK, Lee MY, Lee KG, Yeo JH, Lee WB, et al. Neuroprotection and enhancement of learning and memory by BF7. J Health Sci 2005:51:317-24.

24. Kim YS, Kim KY, Kang PD, Cha JY, Heo JS, Park BK, et al. Effect of silkworm (Bombyx mori) excrement powder on the alcoholic hepatotoxicity in rats. J Life Sci 2008;18:1342-7.

25. Ji SD, Kim NS, Lee JY, Kim MJ, Kweon HY, Sung GB, et al. Development of processing technology for edible mature silkworm. J Seric Entomol Sci 2015:53:38-43.

26. Lee SP, Hong KW, Shon KW, Choi SR, Mah YI, Kim KY. Breeding of new silkworm variety "Baegokjam". Res Rept RDA 1984;26:58-64.

27. Korangy F, Höchst B, Manns MP, Greten TF. Immune responses in hepatocellular carcinoma. Dig Dis 2010;28:150-4.

28. Schneider C, Teufel A, Yevsa T, Staib F, Hohmeyer A, Walenda G, et al. Adaptive immunity suppresses formation and progression of diethylnitrosamine-induced liver cancer. Gut 2012;61:1733-43.

29. DeLisser HM, Christofidou-Solomidou M, Strieter RM, Burdick MD, Robinson CS, Wexler RS, et al. Involvement of endothelial PECAM-1/CD31 in angiogenesis. Am J Pathol 1997;151:671-7.

30. Matsumura T, Wolff K, Petzelbauer P. Endothelial cell tube formation depends on cadherin 5 and CD31 interactions with filamentous actin. J Immunol 1997;158:3408-16.

31. Liaskou E, Wilson DV, Oo YH. Innate immune cells in liver inflammation. Mediators Inflamm 2012;2012:949157.

32. Tian Z, Chen Y, Gao B. Natural killer cells in liver disease. Hepatology 2013:57:1654-62.

33. Bingül İ, Başaran-Küçükgergin C, Tekkeşin MS, Olgaç V, DoğruAbbasoğlu S, Uysal M. Effect of blueberry pretreatment on diethylnitrosamine-induced oxidative stress and liver injury in rats. Environ Toxicol Pharmacol 2013;36:529-38.

34. Luedde T, Beraza N, Kotsikoris V, van Loo G, Nenci A, De Vos R, et al. Deletion of NEMO/IKKgamma in liver parenchymal cells causes steatohepatitis and hepatocellular carcinoma. Cancer Cell 2007;11:119-32.

35. Haybaeck J, Zeller N, Wolf MJ, Weber A, Wagner U, Kurrer MO, et al. A lymphotoxin-driven pathway to hepatocellular carcinoma. Cancer Cell 2009;16:295-308.

36. Vucur M, Roderburg C, Bettermann K, Tacke F, Heikenwalder M, Trautwein C, et al. Mouse models of hepatocarcinogenesis: what 
can we learn for the prevention of human hepatocellular carcinoma? Oncotarget 2010;1:373-8.

37. Shirabe K, Motomura T, Muto J, Toshima T, Matono R, Mano Y, et al. Tumor-infiltrating lymphocytes and hepatocellular carcinoma: pathology and clinical management. Int J Clin Oncol 2010;15: $552-8$.

38. Roderfeld M, Rath T, Lammert F, Dierkes C, Graf J, Roeb E. Innovative immunohistochemistry identifies MMP-9 expressing macrophages at the invasive front of murine HCC. World J
Hepatol 2010;2:175-9.

39. Matsuda M, Nakamoto Y, Suzuki S, Kurata T, Kaneko S. Interferon-gamma-mediated hepatocarcinogenesis in mice treated with diethylnitrosamine. Lab Invest 2005:85:655-63.

40. Shaker ME, Ashamallah SA, El-Mesery M. The novel c-Met inhibitor capmatinib mitigates diethylnitrosamine acute liver injury in mice [published online ahead of print August 20, 2016]. Toxicol Lett. doi: 10.1016/j.toxlet.2016.08.015. 